https://doi.org/10.38129/Ann.Yur.Ist.2020.4.3.84

УДК 347.56:614.25(349.23/24)

\title{
РОЗВИТОК МЕДИЧНОГО ПРАВА НА УКРАЇНСЬКИХ ТЕРЕНАХ У XVIII-XIX СТОЛІТТЯХ
}

\author{
ОЛЬГА ТРОЦЕНКО (Харків, Україна) *
}

В результаті козацького повстання 1648 року, що переросло у повноцінну Визвольну Війну, та укладеного в 1649 році Зборівського мирного договору на теренах України, у складі Київського, Чернігівського і Брацлавського воєводств, а також східних районів Волині та Подільського воєводства, постала нова держава - Гетьманщина, яка, за Березневими статтями 1654 року, перейшла під протекторат московського царя. Однак, внаслідок неодноразового порушення домовленостей та численних договорів Московії з ії сусідами, склад українських територій, що перебували під владою Москви (а пізніше Петербургу) постійно змінювався, тоді як обіцяні Богдану Хмельницькому (1595-1657 рр.) права та автономія обмежувались, допоки зовсім не зійшли нанівець.

В результаті, українські землі стали частиною Російської імперії, увійшовши у вітчизняну історію як Наддніпрянська Україна, котра займала майже всю нинішню територію України, за винятком Львівської, Тернопільської, Івано-Франківської, Закарпатської, Чернівецької областей. У 1783 році до складу Імперії увійшов і Крим. Відтак, на означені історикогеографічні терени Наддніпрянщини і Криму розповсюдили свою дію закони Російської імперії, серед яких були й такі, котрі регулювали питання охорони здоров'я та медицини. Вивчення цих законів Російської імперії, на наш погляд, є важливим елементом у дослідженні становлення та генезису системи медичного права Украйни.

До початку XVIII століття особливої уваги регламентації медичної діяльності не приділялось. Частково питання охорони здоров'я були згадані ще у Церковному статуті Володимира Великого та в Руській правді. Однак, після приходу до влади, цар Петро I (1682-1725) розпочав масове реформування Російської Імперії на європейський лад. Велику увагу було приділено питанням армії та флоту, що мало відношення і до медицини, адже лікарська діяльність завжди нерозривно пов'язувалась з військовою справою, тоді як ијивільна сторона життя 
вважалась, більш-менш, другорядною.

У 1716 році публікується Віӥськовий статуm, який не обійшов стороною і питання медичного забезпечення військ. За цим статутом медичні працівники поділялись на:

Докторів - перебували під безпосереднім керівництвом «вищих генералів», були безпосередніми начальниками усіх інших медичних працівників підрозділів та частин, якими командували ці генерали; призначались доктори 3 числа найбільш досвідчених лікарів, які могли допомогти своїм підлеглим у вирішенні завдань лікування складних хвороб, могли самостійно проводити оперативні втручання. До сфери їхнього відання входив нагляд за польовими аптеками, «дабы оная доволными и добрыми лекарствами и искусными особами снабдена была'»;

Польових аптекарів - їхнім завданням було приготування ліків, вчасне поповнення запасів медикаментів, нагляд за станом лікарських засобів. Також польовим аптекарям належало мати помічників, які б розумілись в аптекарській справі; ампутаціями;

Штап-лікарів - займались «рядовими» операціями, перев’язками,

Польові лікарі та ротні фельдшери - безпосереднє виконання медико-санітарних функцій у підрозділах.

Надання медичних послуг усім військовим здійснювалось безкоштовно. Однак з офіцерів стягувалась плата за лікування ран, які вони отримали у бійках, не пов'язаних з виконанням службових обов'язків, а також за лікування «французьких хвороб» 2 .

Як і сухопутні війська, військово-морські сили так само потребували регулювання медично-санітарної частини, чому і були присвячені глави п'ята і шоста книги першої Морського статуту 1720 року - «О докторе при фрлоте» $\mathrm{i}$ «O главном лекаре при флоте».

Незважаючи на те, що реформи Петра I більшою мірою були успішними, ефективну систему місцевого самоуправління йому створити так і не вдалось, а повстання Пугачова 1773-1775 років продемонструвало всю безпорадність місцевих адміністративних органів. Такий стан справ змусив Катерину II (17621796 рр.) у 1775 році видати уаказ - «Учреждение для управления губерний

1 Устав воинский о должности генералов, фелтмаршалов и всего генералитета и прочих чинов, которые при войске надлежат быть, и о иных воинских делах и поведениях, что каждому чину чинить должно. 1716 г. Электронная библиотека МГУ им. М. Ломоносова. Электронный ресурс: http:/ / www.hist.msu.ru/ER/Etext/Ystav1716.htm.

2 Тобто венеричних захворювань. 
Всероссийской империи».

Серед усього іншого, в указі відводилась певна увага питанням охорони здоров'я. Такі знайшли своє місце у частині «О Приказе Общественного Призрения»3 . До таких відносились: народні школи, сиротинці, госпіталі та лікарні, будинки пристарілих і богадільні, будинки для невиліковно хворих, психіатричні лікарні та гамівні будинки.

Указом регулювались питання розташування лікарень (поза межами великих населених пунктів, вниз за течією річок), вимоги до їх планування та утримання. Задля зменшення навантажень на лікарні, невиліковно хворі утримувались окремо, у спеціальних закладах - будинках для невиліковно хворих.

Для ізоляції психічнохворих від суспільства «Приказу Общеетвенного Призрения надлежит иметь попечение, чтобы дом избран был довольно пространный и кругом крепкий, чтобы утечки из него учинить не можно было4». Штат лікарень комплектувався наглядачами, необхідною кількістю людей для нагляду за хворими, лікарями.

Наказом також регламентувались питання фінансового забезпечення закладів та фінансової звітності надходжень і витрат. Окремо регулювались моменти прийому хворих, їх утримання, харчування, а також штат, посади i завдання відповідно до посадового табелю (розпису).

Медична допомога в таких закладах сочіально незахищеним прошаркам населення надавалась безоплатно, а забезпеченим людям - за незначну плату.

Наступним кроком у формуванні законодавчої бази медичної діяльності став «Свод учреждений и Уставов врачебных по гражданской части» 1842 року, який після доопрацювань, доповнень і редагування був заново виданий у 1857 році, як «Устав врачебный». Його базою стала прийнята за 60 років до того Інструкція лікарським управам, вона ж «Інструкція про упорядкування лікарських управ».

Складався Статут з трьох книг, перша з яких була присвячена лікарсъким установам, друга була статутом медичної поліщї, а третя - статутом судової медицини.

За цим статутом, медицина, у своїй цивільній частині, покладалась на Медичний департамент та департамент казенних лікарських заготівель, які структурно входили до Міністерства внутрішніх справ. До функцій Медичного департаменту відносилось управління медичною частиною, справами судової

3 Правильний переклад: «Про заклади громадської опіки».

4 Уиреждение для управления губерний Всероссийской империи 1775 г. Электронный ресурс: http://museumreforms.ru/node/13634. 
медицини та медичної поліції. У свою чергу, Департамент поділявся на два відділення, перше з яких відало безпосередньо медичною частиною, а другому підпорядковувались органи медичної поліиї та судової медицини.

Згідно комплексу своїх завдань, Департамент казенних лікарських заготівель займався заготівлею лікарських матеріалів, ліків та іншого майна для медичних потреб, їх зберіганням та розподілом. Як і Медичний департамент, він складався 3 двох відділень. Перше відало казенними аптеками, магазинами, садами, заготівлею медичного обладнання. До сфери відповідальності другого входило відання медико-фармацевтичною бухгалтерією.

Також, до складу Міністерства внутрішніх справ входила і Медична Рада, яка була найвищою в краӥні лікарсько-судовою, лікарсько-поліцейською $і$ лікарсько-вченою установою.

Описаний статут був двічі редагований - у 1892 i 1905 роках. Про це ми ще згадаємо далі.

У 1825 році на престол зійшов син Павла I (1796-1801) Микола I (1825-1855), який після виступу декабристів 14 грудня 1825 р. (в момент початку його правління, фактично у день, коли війська та Сенат присягли йому на вірність), остерігався новацій, та увесь час свого правління прикладав багато зусиль до зміцнення самодержавства і придушення усіх можливих проявів опозиції. Через це, цілих 30 років його правління можна охарактеризувати як застій - відмова від усіляких реформ та нововведень. Тому, коли у 1855 році імператорський престол зайняв його син Олександр II (1855-1881), останній отримав країну, спраглу до реформ.

У 60-x роках XIX ст. здійснились наймасштабніші від часів Петра I реформи. Однією з них стала земська реформа 1864 року, яка серед іншого мала безпосередній вплив і на галузь охорони здоров'я, запровадивши систему земської медицини.

До сорери діяльості земської медицини належали:

а) надання медичної допомоги сільькому населенню в губерніях $i$ повітах, допомога при пологах;

б) боротьба з заразними хворобами, особливо сифілісом та віспою;

в) санітарний нагляд і практичні санітарні заходи;

2) санітарна статистика;

д) розповсюдження знань про гігієну серед населення а пакож знань про права та обов'язки лікарського персоналу в земствах.

У перші роки земської реформи діяла так звана роз'їза система медичного обслуговування - лікар, який жив у місті чи повіті при амбулаторії, повинен був 
час від часу об'їжджати фельдшерські пункти повіту, якими керували фельдшери, що мали лише короткострокову медичну підготовку (курси).

Така система не влаштовувала лікарів, які замість надання медичної допомоги постійно знаходились в роз'їздах. Відтак, ії згодом замінили на т. зв. стаціонарну медицину.

До системи закладів охорони здоров'я входила мережа лікарень, лікарських дільниць та фельдшерських пунктів, які розподілялись за територіальним принципом. Існувало два рівні медичних закладів на місцях губернські $i$ nobimoвi. До губернських відносились: губернська земська лікарня, лікарня психічно хворих, губернська аптека, фармацевтична лабораторія, фельдшерська i акушерська школи, віспове відділення. Інші ж пункти відносились до повітових, в основному це були фельдшерські пункти та лікарні, які, в основному, і займались лікуванням хвороб. Територію повітів було поділено на земські лікарняні дільниці.

Законодавство, щуо регулювало діяльність земських медичних закладів, можна поділити на чотири рівні:

перший рівень - імператорські законодавчі акти (до таких, перш за все, необхідно віднести Положення про губернські і повітові земські установи 1864 та 1890 років, як основу діяльності таких установ. Що ж стосується безпосередньо медико-санітарної діяльності, то вона здійснювалась на основі вищезгаданого Статуту);

другий рівень - акти Державної Ради, Сенату, Ради міністрів, Комітету міністрів;

третій рівень - декрети та циркуляри центральних органів управління, особливо це стосується Міністерства внутрішніх справ, Міністерства фінансів, Медичного департаменту, Головного лікарського інспектора;

четвертий рівень - циркуляри, розпорядження та інші акти органів і посадових осіб на місцях - губернатора, і губернських по міських справах (з 1892 р.), губернських лікувальних відділів, повітових лікувальних управ, постанови губерських і повітових земських зборів.

До установ, що безпосередньо забезпечували діяльність медичних закладів на місцях відносились губернські і повітові земські збори та губернські і повітові управи. Перші приймали земські нормативно-правові акти, а другі, більшою мірою, були виконавчими органами.

У 1892 році в Санкт-Петербурзі, видавництвом кодифікаційного відділу при Державній Раді Російської імперії, було опубліковано нову редакцію Лікарського статуmу, який дає змогу детально проаналізувати стан медичного 
законодавства станом на кінець XIX століття. Складався він 3 трьох книг: перша була присвячена лікарським закладам, друга - медичній поліції, третя - судовій медицині.

Перша книга відводила фрункиію управління ициільною лікарською частиною Міністерстьу bнутрішніх справ, в якому вона поділялась між Медичним департаментом, Медичною радою і Поєднаним ветеринарним комітетом, яким підпорядковувалось локальне медичне врядування. Однак лікарські управління в областях війська Донського, а також в козачих військах підпорядковувались Військовому міністерству. Придворною ж медичною частиною завідував Інспектор лікарської частини Міністерства Імператорського Двору.

До місцевого лікарського управління в губерніях і областях належали також:

1) Управління сільською лікарською частиною;

2) Управління різних лікарських закладів і мінеральних вод;

3) Комітети суспільного здоров' я;

4) Віспові комітети;

5) Карантинні управління.

Функції кожної з цих установ детально розписувались в Статуті.

У кожній губернії передбачалось мати по одному повітовому лікарю на повіт, ветеринарів та їхніх помічників, кількість яких визначалась штатом i особливими розпорядженнями та повітових фельдшерів, кількість яких так само визначалась штатами і особливими розпорядженнями.

Дворянам і помішикам надавалось право мати на своєму утриманні власних лікарів, які б надавали їм медичну допомогу відповідно до правил, прописаних Статутом.

Усі медичні чини в губерніях підпорядковувались губернським лікарським управам.

Також увага була приділена і питанням надання права на медичну діяльність іноземним лікарям. Ці питання відносились до компетенції Медичної Ради Міністерства внутрішніх справ. Такі лікарі могли допускатись до практики після здачі звичайного екзамену і отримання вченого ступеня; «більш відомі» закордонні лікарі мали право отримати ліцензію на практику лише після словесного екзамену (colloquim) в Медичній Раді; а тим «которые сдплали себп имя въ ученомъ свптп свочми сочиненіями или усппшною практикою, или занимали профресорскія каӨедры или же важныя по медицинской части мпста въ других 


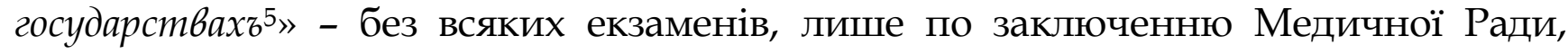
затвердженому Міністерством внутрішніх справ.

Також перша книга регулювала порядок здобуття медичних учених ступенів і звань у розділі «объ испытаніи мищъ, посвящающихъ себя службп по медицинскому впдомству или практикп врачебной»б. Так, вчені звання поділялись на:

\section{I. Медичні:}

1) спеціально-практичні: зубний лікар, дантист, повивальна бабка;

2) учено-службові: повітовий лікар, члени лікарської управи - акушер і оператор, інспектор лікарської управи;

3) учено-практичні: лікар, доктор медицини, доктор медицини і хірургіi.

\section{II. Фармацевтичні:}

1) аптекарський помічник;

2) провізор;

3) магістр фармацевтики (аптекар).

\section{III. Ветеринарні:}

1) ветеринарний помічник;

2) ветеринар;

3) доктор ветеринарних наук.

Друга книга, Статут медичної поліиії, містила правила по захисту здоров’я населення від усього, що могло мати на нього шкідливий вплив, особливо 3 приводу запобігання і припинення епідеміü, а також 3 приводу захисту домашньої худоби від падежу і хвороб.

На медичну поліцію покладались функції захисту чистоти повітря, оцінки безпеки харчових припасів, а також нагляд за дотриманням правил продажу ядовитих і сильнодіючих речовин.

Цим же Статутом встановлювались вимоги до поховання мертвих та облаштування кладовищ.

Задля запобігання розповсюдженню епідемій, імперські законодавці не

5 Устав врачебный: Свод законов Российской империи. Том 13. Изд. 1892 г. Санкт-Петербург: Кодификац. отд. при Гос. совете, 1892. Ст. 18.

6 Устав врачебный: Свод законов Российской империи. Том 13. Изд. 1892 г. Санкт-Петербург: Кодификац. отд. при Гос. совете, 1892. Ст. 95. 
обійшли увагою і такі моменти як віспощеплення та карантини ${ }^{7}$ а також вказівки щодо дій уповноважених на те осіб( так званої «карантинної стражі»), у разі, якщо епідемічна хвороба була все ж таки виявлена.

Третя книга Статуту - статуm судової медицини - своїми статтями регулювала правила проведення судово-медичних досліджень у кримінальних справах, а, як вказано в примітці до статті 1316: «Постановленія о врачебныхъ осмотрахъ по дпламъ управленія и по дпламъ гражданскимъ изложены въ статьяхъ 3739» 8 .

Якщо дві перших глави статуту регулювали загальні питання про судову медицину, порядок проведення розтину та судово-медичних досліджень, оформлення актів дослідження, то далі йшла детальна інструкція по дослідженню голови; ротової порожнини, шиї і хребта; грудної порожнини; черевної порожнини; правила проведення розтину та дослідження мертвих новонароджених; правила проведення розтину при підозрі на отруєння. Дев'ята глава знову від конкретики повертається до загальних питань дослідження ушкоджень.

Згодом, у 1905 році, як уже зазначалось, Лікарський статут вийшов у новій редакції.

На рубежі XIX та XX століть відбулась незначна демократизація життя в Російській імперії, була створена велика, як для того часу, кількість партій, конституювались профспілки, посилювався робітничий рух. Під впливом нових факторів соціально-політичного життя влада була вимушена піти на певні поступки, при цьому зберігши свої позиції протистоянні опозиційнореволюційним настроям. Проявом такого збереження позицій є прийнятий у 1903 році Закон «Про винагороду потерпілих внаслідок нещзасних випадків робітників $i$ службовиів, членів їх сімеи у підприємствах гірничої та гірничозаводської промисловості». 3 одного боку, цей закон поліпшував становище працівників, надаючи їм гарантії матеріального забезпечення у випадку отримання виробничих травм. 3 іншого ж боку, відповідальність за отримані робітниками на виробництві травми лягала на підприємця, тим самим покладаючи на нього тягар компенсації перед працівником, оберігаючи державну скарбницю від форс-мажорних витрат.

7 Маються на увазі прикордонні карантини, що мали убезпечити окремі території імперії від занесення чуми, жовтої гарячки, азіатської холери та деяких інших особливо небезпечних хвороб.

8 Устав врачебный: Свод законов Российской империи. Том 13. Изд. 1892 г. Санкт-Петербург: Кодификац. отд. при Гос. совете, 1892. Ст. 215. 
Революція 1905-1907 років змусила законодавчий апарат Імперії активізуватись, адже армія могла навести порядок та придушити виступи, але самої лише сили було недостатньо для замирення виразних проявів соціального невдоволення. У 1906 році пост прем'єр-міністра зайняв П. А. Столипін, який хоч $\mathrm{i}$ був досить жорстким та прикладав усіх зусиль для зміцнення самодержавства, проте розумів необхідність поступок на користь новосформованого класу робітників (рушія модернізованої промисловості). Для цього, уряд підготував цілий пакет законопроектів. Однак, 3 огляду на внутрішні коливання серед міністрів, ці проекти законів досить довго розглядались, відправлялись на доопрацювання або просто відхилялись. Зрештою, у 1912 року, вже після вбивства Столипіна, було прийнято чотири із запропонованих ним законів. Серед них особливо важливі: «Про забезпечення робітників на випадок хвороби», «Про запровадження Ради зі справ страхування робітників», «Про запровадження присутніх зі справ робітників». Однак, одночасно зі вступом в силу цих законів, не сталось скасування суперечливого закону 1903 року, що спричиняло правові колізії та зменшувало ефективність «столипінських» законів.

При дослідженні медичного законодавства Російської імперії неможливо обійти стороною виданий Н. Г. Фрейбергом збірник «Врачебно-санитарное законодательство в России», який містив більшість діючих станом на 1 січня 1913 року нормативно-правових актів, регулюючих суспільні відносини у сфері охорони здоров' я.

Зауважимо: хоча Н. Г. Фрейбергом і була проведена значна робота 3 упорядкування діючих норм, це була лише наукова робота, без претензій на кодифікацію. Разом із тим, текст Фрейберга міг би стати чудовою базою для ухвалення єдиної медико-правової кодифікації.

Здебільшого збірник опирається на Санітарний статуm, в редакції від 1905 року. Однак були і й такі нормативно-правові акти, які сфери медицини торкались опосередковано:

том I, ч. 2 - «Установи Міністерств» від 1892 р.;

том II - «Загальні губернські установи» від 1892 р.;

том II - «Положення про губернські і повітові земські установи» від 1892 р.;

том II - «Міське положення» від 1892 р.;

том II - «Управління земським господарством у західних губерніях» від 1906 р.;

том III - «Статут про службу за урядовим призначенням» від 1896 р.;

том III - «Cтатут про пенсії $і$ одноразову грошову допомогу» від 1906 р.;

том III - «Положення про особливі переваги служби у віддалених місиях» від 1906 
p.;

том V - «Статут акциизних зборів» від 1899 р.;

том VII - «Статут гірський» від 1899 р.;

том XI ч. 2 - «Статут про промисловість» від 1893 р.;

том XII ч. 1 - «Статуm будівельниӥ» від 1893 р.;

том XIII - «Статут громадської опіки» від 1892 р.

Крім того, у доповненні до збірника, Фрейберг навів перелік законів і розпоряджень, які не увійшли у збірку, проте мали відношення до медичного законодавства. Це були, здебільшого, індивідуально-правові акти.

Так, постановою Військової ради, від 21.03.1912 р. додатково засновувались 10 фельдшерських пунктів в Уральському козачому війську. А постановою від 22.05.1912 р. встановлювався граничний вік перебування на службі жінок-лікарів Туркестанського краю9: завідуючі лабораторіями для корінного населення - 60 років, дільничі лікарі - 56.

Що ж стосується актів, які мають безпосереднє відношення до України, то до таких відноситься циркуляр Міністерства внутрішніх справ від 05.08.1912 р. № 778 «Цензура оголошень, які видаються окремими листами або у вигляді брошюр». Даний циркуляр більшою мірою можна назвати актом-роз'ясненням. Так, відповідно до ст. 23 Лікарського статуту 1905 року, компетенції губернських лікарських управ належав розгляд i затвердження до друку оголошень про продаж ліків та способи їхнього вживання, «якщо такі оголошення видаються не тільки «у відомостях або інших періодичних виданнях», але й якщо вони видаються «окремими листами». Циркуляром роз'яснено, що дані слова не потрібно трактувати у тому контексті, що інформація, яка розміщена на 2-х та більше листах не потребує затвердження, так як стаття закону «импетъ въ виду прежде всего содержаніе печатаемаго, а не его размпръ»10.

Цікавим актом є також постанова Медичної ради від 07.09.1910 р. №1038, якою дозволявся ввіз та продаж за рецептами лікарів у аптеках на території Імперії ряду лікарських засобів закордонного виробництва.

Таким чином, протягом двох століть, у період перебування Наддніпрянської України в Російській імперії, система медичного права здійснила грандіозний ривок до повноцінної галузі юриспруденції - зі своїми законами, статутами та циркулярами. Станом на 1913 р., повноцінно

9 Заклади охорони здоров'я в Туркестанському краї перебували у віданні Військової ради.

10 Фрейберг Н. Г. Врачебно-санитарное законодательство В России. С.-Петербург: Практическая медицина, 1913. С. 1051. 
функціонували відповідні відомства, що регулювали медико-правові відносини - Медична рада, Медичний департамент та Поєднаний ветеринарний комітет Міністерства внутрішніх справ.

Основою медико-санітарного законодавства був Лікарський статут. Однак, використовувались норми й інших галузей права - кримінального, податкового, трудового. Не обійшлось без законодавства, що регулювало суспільні відносини у сфері гірничої, будівельної промисловості та промисловості в цілому, а також без нормативно-правових актів 3 питань соціального забезпечення. Що ж стосується медицини у армії і на флоті, а також деяких окремих регіонів держави (передусім, областей козачих військ), то там медичні правовідносини регулювались відповідними актамии військового міністерства.

PhD in Law Olga Trotsenko (Kharkiv, Ukraine)

The Development of Medical Law in the Ukrainian Lands in the XVIII-XIX centuries

The article examines specific institutional examples of medical law development in the Ukrainian lands that were part of the Russian Empire. The question of the interaction of imperial medical law with other branches of jurisprudence is investigated. The basic principles of practical law enforcement of the rules of imperial medical law are stated. Attention is drawn to the issues of doctors' status and titles, zemstvo medical reform, and Stolypin regulation of occupational medicine.

Key words: Medical Law, Zemstvo Medicine, Medical Charter, Ministry of Internal Affairs.

кандидат юридических наук Ольга Троценко (Харьков, Украина)

Развитие медицинского права на украинских землях в XVIII-XIX вв.

Статья рассматривает конкретные институциональные примеры развития медицинского права на украинских землях, входивших в состав Российской империи. Исследуется вопрос о взаимодействии имперского медицинского права с иными отраслями юриспруденции. Изложены основные принципы практического правоприменения норм имперского медицинского права. Обращено внимание на вопросы статуса и титулов врачей, земской медицинской реформы, столыпинского регулирования медицины труда.

Ключевые слова: медицинское право, земская медицина, Устав Врачебный, Министерство внутренних дел.

кандидат юридичних наук Ольга Троценко (Харків, Україна)

Розвиток медичного права на українських теренах у XVIII-XIX ст.

Стаття розглядає конкретні інституційні приклади розвитку медичного права на 
українських землях, що входили до складу Російської імперії. Досліджується питання про взаємодію імперського медичного права 3 іншими галузями юриспруденції. Викладено основні принципи практичного правозастосування норм імперського медичного права. Звертається увага на питання статусу і титулів лікарів, земської медичної реформи, столипінського регулювання медицини праці.

Ключові слова: медичне право, земська медицина, Лікарський Статут, Міністерство внутрішніх справ.

* Троценко Ольга Вікторівна - кандидат юридичних наук, адвокат, директор Адвокатського бюро «Ольги Троценко».

E-mail: ov.trotsenko1@gmail.com 